\title{
Flipping the Nursing Classroom: Engaging the Students to Build Competency
}

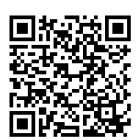

\author{
Selvia Arokiya Mary A* \\ Department of Medical Surgical Nursing, University of Bisha, Saudi Arabia
}

Submission: January 22, 2020; Published: January 30, 2020

*Corresponding author: Selvia Arokiya Mary A, Department of Medical Surgical Nursing, University of Bisha, Saudi Arabia

\begin{abstract}
As with most strategies, the flipped classroom has a variety of ways to implement in the classroom. This article is a case study of the flipped classroom. It reviews and provides research on the implementation of the flipped classroom. In addition, the article provides a variety of implementation methods and tools to be utilized in a flipped classroom. The traditional classroom has always been "I Do", "We Do", "You Do" as a strategy for teaching but flipped classroom truly flips that strategy. The teacher uses "You Do", "We Do", “I Do". Homework, inquiry, and investigation happen in the classroom. At home students participate in preparation work including watching videos, PowerPoint's, and completing readings. After completing the preparation work, students arrive in class ready to start solving problems, analyzing text, or investigating solutions. The flipped classroom is new in the teaching field as a strategy for teaching.
\end{abstract}

Keywords: Flipped Classroom; Teaching Strategies; Education

\section{Introduction}

The flipped classroom is new in the teaching field as a strategy for teaching. It has been used by teachers from elementary school to graduate school. As with most strategies, the flipped classroom has a variety of ways to implement in the classroom.

\section{Why the Flipped Classroom}

According to Strohmyer applying flipped classroom strategy achieves many benefits. These benefits include that flipped classroom: a) guarantees for teacher making good use of classroom period; so, he/she makes use of time in guiding and helping

b) enhances the critical thinking, self- learning, building experiences, communication skills, and cooperation among students

c) provides a technique to evaluate the students' understanding because tests and short tasks that students perform are indicators of weaknesses and strengths in their understanding of content (Figure 1).

\section{TRADITIONAL CLASSROOM}

- Students do readings at home and print out power point notes for lecture

- Instructor prepares lecture materials

- Students listen to lecture by instructor

- Students take notes on the lecture

- The instructor is the center of the class

- The instructor is in control of class time

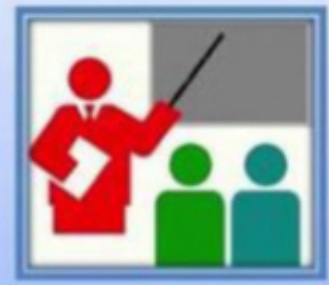

Figure 1: Stanton Number Values versus Tube Length. 
The other positives of flipped classroom that include:

a) developing the role of teacher as a lecturer to become a guide and supervisor, and developing the role of student to become a researcher participating in the teaching and learning processes b) helping students' self- learning according to their abilities and individual differences

c) providing students with excited educational environment and enhancing high thinking skills such as critical thinking skills (Figure 2).

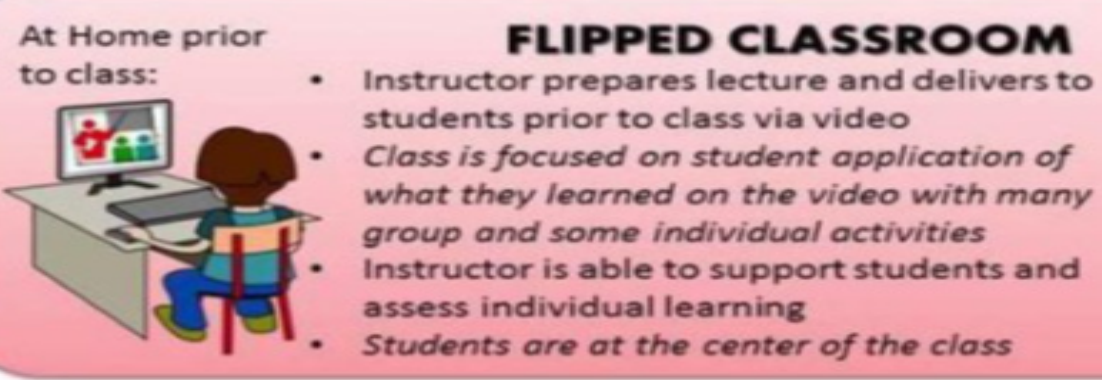

Figure 2: Stanton Number Values versus Tube Length.

\section{Flipping Your Classroom}

Flipping your classroom does not mean you can never lecture or that your classroom is always flipped. The teacher is still necessary in the flipped classroom. The teacher still must plan and prepare for every class. The flipped classroom also does not require technology to use.

The following 5 tips for flipping your classroom:

a) Don't get hung up on creating your own videos.

b) Be thoughtful about what parts of your class you decide to "Flip" and when.

c) If possible, find a partner to create videos with.

d) Address the issue of access early.

e) Find a way to engage students in the videos.

A common practice of teachers utilizing a flipped classroom is videos of the lectures (Table 1). The videos are used in various ways. Teachers found that the use of short 10-15-minute videos is the best way to incorporate the videos. Resources have surfaced on the web of content information in a wide range of subject matter. Some websites provide premade videos, tutorials, and interfaces on the subject matter. The most successful flipped classrooms report that they utilize videos of the content that they have gotten from a variety of places. By obtaining videos from other sources the students indicate they are more engaged and found the information refreshing (Figure 3). Videos from the same person can become mundane and boring. Students will disengage and are likely not going to watch them with their full attention. One means of making the videos is the use of simple "one take" videos [1]. "To create these videos, all you need is an inexpensive digital camera, tripod, white panel board, and dry erase markers. Teachers outline their presentation with visual aids on a series of small whiteboards. Then, they simply record themselves talking through the series of whiteboards. The benefit of this approach is that videos can be created quickly; and by having the teacher on camera, students connect with both the content and their teacher." Budget constraints do not have to prevent a teacher from utilizing the flipped classroom [2].

Table 1: Flipped Classroom Strategy

\begin{tabular}{|c|c|c|}
\hline Pre-Session & During Session & Post Session \\
\hline \multirow{2}{*}{ Reading } & Active learning strategies & Review \\
\cline { 2 - 3 } & Cases & Reading \\
\hline Watch video & Worked examples & Practice problems \\
\hline \multirow{2}{*}{ Listen /watch pre-recorded lecture } & Discussions/debate & Synthesis/application activity (e.g cases) \\
\cline { 2 - 3 } & Quizzes, debrief \\
\hline \multirow{2}{*}{ Practice patient case } & Simulation & Skill practice \\
\cline { 2 - 3 }
\end{tabular}




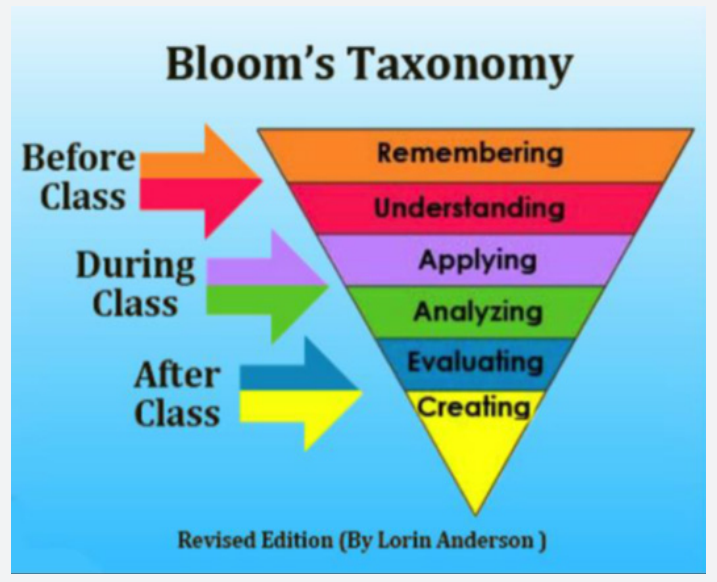

Figure 3: Flipping Bloom's Taxonomy.

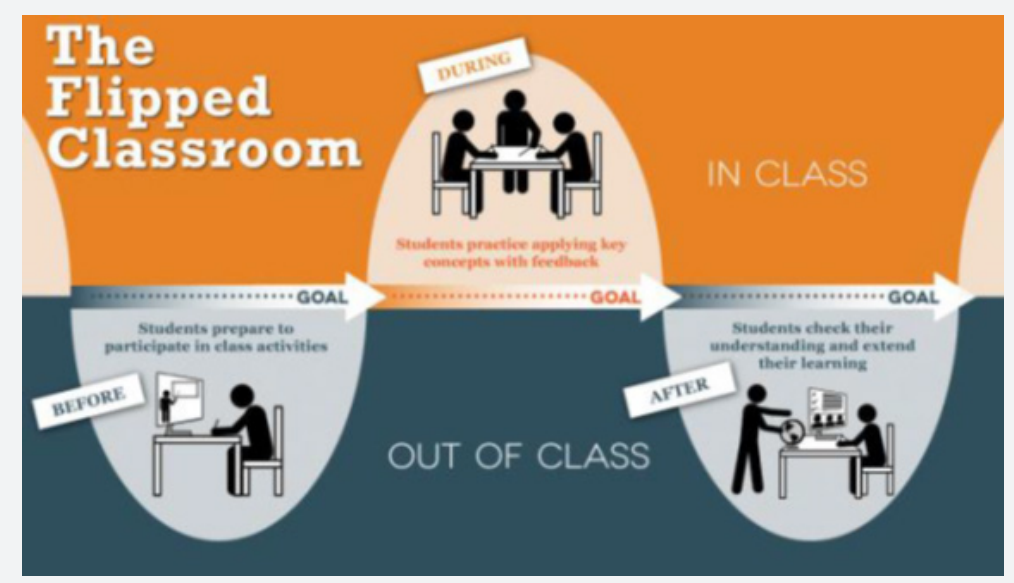

Figure 4: The Flipped Classroom Goal.

The first consideration that must be made when incorporating a flipped classroom is what technology is available to not only the teacher but the students as well (Figure 4). If a teacher requires students to use the internet or view videos for homework, the students need to have access to this technology. Some teachers are shocked to discover how many of their students still do not even have a computer at home let alone access to the internet. Some teacher's work addresses this by creating a means to provide access to these students while other teachers change their medium away from the computer. Whether it is watch videos or complete a reading, the teacher cannot just require the task to be completed. The student needs to be engaged in the process to assure its completion and the students acquiring the knowledge presented. This can be done in many ways. Teachers are even getting creative with this aspect of the flipped classroom [3]. It can be as simple as having the students complete a worksheet or answer questions as they read or watch the video. Having the students write questions about what further information they need is helpful in moving to the in-class portion of the lesson. Having the students identify and define words they were not familiar with is also helpful [4].

Why might you consider using the flipped classroom model?

a) Interactive learning -engagement of students

b) Assessment of student learning

c) Deeper ability to connect with each student

d) Real time assessment ability

e) Can correct errors of thinking

f) Moves the classroom in to the $21^{\text {st }}$ century

g) Uses technology that students are already using

h) Research is proving it is effective -flipped learning is evolving and becoming more evidence based 


\section{When do I know I am ready to flip?}

a) Can I access and use screen capture software?

b) Do I have space for the active learning I want to do in the live classroom?

c) Have I discussed this method with my students and me?

d) Do I have flipping colleague to help me

e) Do I have good tech support at my institution?

\section{What technology can I use for flipping?}

Flipping is not all about the technology but there is a lot of helpful technology to use, Some examples:

a) Screen capture software programme

b) Document camera

c) Whiteboards - can be high or low tech

d) Pickers - like clickers but with paper

e) Student self-made videos, wikis, interactive content pages in LMS

f) Apps (white boards, recording apps, A \& P, so many)

g) Virtual technology for application in classroom

\section{Conclusion}

\section{The IOM (2011) has challenged nurse educators to close the classroom - practice gap}

Nurse educators can no longer rely on delivering content laden curriculum using traditional lecture style delivery methods, this flipped classroom method will Implement active learning strategies congruent with andragogical principles to improve clinical judgement nursing students [5,6]. The learning activities will bring clinical experience into classroom provide nursing students with the opportunity to practice making clinical judgments Address the classroom practice gap.

\section{References}

1. Storm DA, McKeon RJ, McKinzie HL, Redus CL (1999) Drag Reduction in Heavy Oil. J Energy Resour Technol 121(3): 145-148.

2. Rached BM, Pervez A, Habib MA (2015) Simulation of Oxy-fuel combustion of heavy oil fuel in a model furnace. J Energy Resour Technol 137(3): 032206.
3. Shadi WH, Mamdouh TG, Nabil E (2010) Heavy crude oil viscosity reduction and rheology for pipeline transportation. Fuel 89(5): 10951100.

4. Martnez PR, Mosqueira ML, Zapata RB, Mar JE, Bernal HC, et al. (2011) Transportation of heavy and extra-heavy crude oil by pipeline: a review. J Pet Sci Eng 75(3-4): 274-282.

5. Elphingstone GM, Greenhill KL, Hsu JJC (1999) Modeling of Multiphase Wax Deposition. J Energy Resour Technol 121(2): 81-85.

6. Weissman JG (1997) Review of processes for downhole catalytic upgrading of heavy crude oil. Fuel Proc Technol 50(2-3): 199-213.

7. Rana MS, Stomano V, Ancheyta J, Diaz JAI (2007) A review of recent advances on process technologies for upgrading of heavy oils and residua. Fuel 86(9): 1216-1231.

8. Naseri A, Nikazar M, Mousavi DSA (2005) A correlation approach for prediction of crude oil viscosities. J Pet Sci Eng 47(3-4): 163-174.

9. Hossain MS, Sarica C, Zhang HQ (2005) Assessment and development of heavy-oil viscosity correlations. In: SPE International Thermal Operations and Heavy Oil Symposium, Kalgary, p. 1-9.

10. Alomair O, Elsharkawy A, Alkandari H (2011) Viscosity prediction of Kuwaiti heavy crudes at elevated temperatures. In: SPE Heavy Oil Conference and Exhibition, Kuwait, p. 1-18.

11. Yigit AS, Christoforou AP (2006) Stick-Slip and Bit-Bounce Interaction in oil-well Drillstrings. J Energy Resour Technol 128(4): 268-274.

12. Barrufet MA, Setiadarma A (2003) Reliable heavy oil-solvent viscosity mixing rules for viscosities up to $450 \mathrm{~K}$, oil-solvent viscosity ratios up to $4 \times 10^{5}$, and any solvent proportion. Fluid Phase Equilib 213(1-2): 65-79.

13. Luis FA, Doruk A (2008) Evaluation of "Marching Algorithms" in the Analysis of Multiphase Flow in Natural Gas Pipelines. J Energy Resour Technol 130(4): 043003.

14. Yilin WJ (2011) Well Completion for Effective Deliquification of Natural Gas wells. J Energy Resour Technol 134(1): 013102.

15. Chuan L, Huiqing L, Qiang Z, Qingbang M (2014) Experimental Study of Reasonable Drawdown Pressure of Horizontal Wells in Oil Reservoir with Bottom Water. J Energy Resour Technol 136(3): 034502.

16. Junlai W, Yuetian L, Haining Y (2012) New Method of Productivity Equation for Multibranch Horizontal Well in Three-Dimensional Anisotropic Oil Reservoirs. J Energy Resour Technol 134(3): 032801032801, p. 1-5.

17. Anuj G (2012) Performance Optimization of Abrasive Fluid Jet for Completion and Stimulation of Oil and Gas Wells. J Energy Resour Technol 134(2): 021001.

18. Bhuwakietkumjohn N, Rittidech S (2010) Internal flow patterns on heat transfer characteristics of a closed-loop oscillating heat-pipe with check valves using ethanol and a silver nano-ethanol mixture. Exp Therm Fluid Sci 34(8): 1000-1007. 


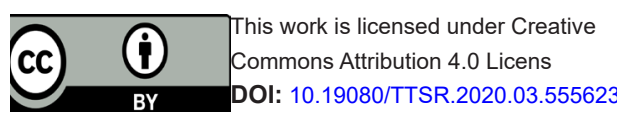

Your next submission with Juniper Publishers will reach you the below assets

- Quality Editorial service

- Swift Peer Review

- Reprints availability

- E-prints Service

- Manuscript Podcast for convenient understanding

- Global attainment for your research

- Manuscript accessibility in different formats

( Pdf, E-pub, Full Text, Audio)

- Unceasing customer service

Track the below URL for one-step submission https://juniperpublishers.com/online-submission.php 